\title{
Training in the Financial Industry: An Effectiveness Study on a Small EU Island State
}

Submitted 16/11/20, 1st revision 11/12/20, 2nd revision 20/01/21, accepted 19/02/21

\author{
Yanika Gauci $^{1}$, Simon Grima ${ }^{2}$, Yannis Thalassinos ${ }^{3}$, Inna Romanova ${ }^{4}$
}

\begin{abstract}
:
Purpose: This study explores key factors that have a significant impact towards training effectiveness within the Maltese financial industry.

Design/Methodology: In order to reach the aim of this study, training institutions and other financial organisations delivering training to employees working within the financial industry were contacted. The authors used a mixture of methods, whereby observations and self-administered questionnaires assisted in the data collection for this study.

Findings: Findings show that the Maltese financial industry is providing effective training to its employees and that mature trainees with a higher level of occupation found the training more effective than others. Furthermore, the proposed Training Effectiveness Model (TEM) leads to an improved employee performance, as it positively correlates with the Employee Performance Development Model (EPDM) established in this study.

Practical Implications: Research exhibited that training needs analysis, clear training objectives and expected outcomes, trainee characteristics, training design and work environment are the main factors of a strategic and effective employee training.
\end{abstract}

Keywords: Training effectiveness, employee development, financial industry, Malta.

JEL classification: M53, D53, G1.

Paper type: Research study.

\footnotetext{
${ }^{1}$ Department of Insurance, Faculty of Economics, Management \& Accountancy, University of Malta.

${ }^{2}$ Assoc. Professor, Department of Insurance, Faculty of Economics, Management \& Accountancy, University of Malta, simon.grima@um.edu.mt

${ }^{3}$ Ph.D., Adjunct Lecturer GUST University of Kuwait, thalassinos@hotmail.com

${ }^{4}$ Professor, Faculty of Business, Management and Economics, University of Latvia, Riga, Latvia,inna.romanova@lu.lv
} 


\section{Introduction}

We are currently living in an era where there is a significant increase in competition, between organisations operating within the same industry; all of which are striving for success. Given the increase in competition, organisations need to be aware and maintain efficient management of human resources (Nassazi, 2013). According to Jack Welch as cited by Barnett (2016), "an organisation's ability to learn and translate that learning into action rapidly, is the ultimate competitive advantage". Training of employees is one area that is imminent for organisations to maintain competitiveness in today's rapidly changing business environment (Mzimela and Chikandiwa, 2017). However, organisational leaders have been in long-standing neglect and recognised employee training and development as a minor activity with little or no effect towards the organisation's outcome (Yaqoot et al., 2017). On the other hand, successful companies acknowledged that an organisation's important asset is its 'human capital'. Enhanced knowledge, skills and capabilities are the elements allowing the achievement of an organisation's competitive advantage within today's global market (Wangchuk and Wetprasit, 2018; Rodriguez and Walters, 2017).

Training is aimed at connecting the disparity between the existing performance scenario and the desired performance of the employee. However, organisations must have a clear structure that assists them to outline and implement a training programme that accomplishes the identified training needs (Denby, 2010). The proper implementation of such programmes results in numerous benefits leading to overall organisational enhancement. To attain that competitive advantage, organisations aspire to be known for their unique services, products and capabilities. However, to maintain such elements, it needs to be conceptualised, developed, and sustained by a well-trained workforce (Rodriguez and Walters, 2017). Organisations have been allocating considerable investments in the professional employee development area; more than $€ 110$ billion a year are spent on employee training and development (European Parliamentary Research Service, 2019). Just about $75 \%$ of the international training investment takes place in Europe, India, Asia, and North America (Jain, 2015).

Rothwell and Kazanas (2011) suggest that training not only improves the bottom line of the situation, but it also saves costs. However, one should keep in mind that a successful training programme delivered yesterday, might not be a costefficient programme to be delivered in the future. In the changing phase of the financial market, all financial firms have numerous opportunities to take on and several challenges to meet. It is the responsibility of an organisation's management to adapt to certain changes and meet the necessary training requirements of their workplace (Sudhakar and Rabiyathul Basariya, 2017).

Employee training has shifted from being merely job oriented, towards focusing on skills development and motivating an attitude to serve (Jain, 2015). Therefore, 
training be a significant element that helps an organisation to develop a dynamic approach. A dynamic approach is essential because organisations that opt for a controlled way of functioning could restrict them to deliver consistent results, but on the other hand a dynamic and flexible organisation may do so (Sudhakar and Rabiyathul Basariya, 2017). A well-thought training programme is a prerequisite,

but it is not the ultimate goal (Foshay and Tinkey, 2007). The organisation's effort is not complete until the outcomes are measured and evaluated (Jain, 2015). Through the evaluation process the organisation collects feedback from participants. This determines whether the training programme provided, meets the expected outcomes (Kurniawati et al., 2017). An organisation goes through a lot of pressure to achieve and maintain a skilled and talented workforce.

Considering the importance of training, the aim of the paper is to explore the key factors that have a significant impact towards training effectiveness within the Maltese financial industry.

\section{Literature review}

Many papers have been written about the significance of training and its impact on employee performance. Nagar (2009) for example examines the effectiveness of training programmes delivered in staff training centres within both private and public commercial banks. The study concluded that a systematically structured training programme helps to motivate employees. Nagar (2009) investigated the effectiveness of training programmes with respect to certain selected variables of the study. Data is collected through structured questionnaires, which focus on the opinions of the trainees in relation to various aspects of the training. Similarly, Ramachandran (2010) investigated the effectiveness of training programmes but this time focusing on the public sector. The study indicates a discrepancy between the employee's perceptions in relation to demographics and training effectiveness. Petkova (2011) continues to explore how to 'Optimize Training Effectiveness'. The study proves that when a training programme is in line with the trainee's motivational orientation a sequence of effective training outcomes was being noted. Rana (2016) assessed 'The impact of Training Design and Development on Employee's Performance Insurance sector in Kingdom of Saudi Arabia'. She concludes that training is a key element towards the improvement of employee performance. Furthermore, there is a significant relationship between training design, training, and development as well as employee performance.

Studies have shown that the right investment in employee training within an organisation will make that organisation competitive in today's evolving environment. Lyons (2008), cited by Mzimela and Chikandiwa (2017), maintains that throughout this turbulent business environment, organisations have no other option but to swim with the tide to remain competitive. This study strives to shed awareness on how one can survive the tide with an efficient well-planned training provided to the workforce. 
A study carried out amongst the employees of the labour market in the Caribbean small island developing states, indicated that the level of required in-firm training opportunities were not sufficient. Training is usually not provided to employees in most Caribbean islands unlike larger Latin American countries. Two surveys carried out in 2014 and 2010 respectively, namely the 'Compete Caribbean's Productivity Technology Innovation' and 'World Bank Survey' aimed to provide a representative sample of an economy's private sector while covering a wide range of business areas. These surveys concluded that firms within the Caribbean were not providing adequate training to their workers. This was a major obstacle in hiring workers, leading to lack of productivity and innovation (Mohan et al., 2018).

Furthermore, throughout the years, literature has not compromised to define the ultimate effect between demographic variables and its impact on training effectiveness, within the financial industry. With this study, the authors aim to explore this concept further using the seven demographic characteristics (gender, age, level of education, industry sector, occupational status, type of employment and current occupation) and their impact on the proposed TEM. Following the latter, they continue to investigate how the TEM reflects towards the development of the employee performance, following the training received.

We use the Maltese financial industry as the basis of our study to determine the importance of training effectiveness and employee performance as per the conceptual framework proposed in this study. Studies carried out in a small state have already proven to be valuable by various researchers to the likes of for example Brigulgio (1995), King (1993) and Bezzina et al., (2014). One can access the data of the whole population, which only few other countries could have, as it would be impossible to do so in larger states (Carabott, 2019). Small countries are also able to exhibit more transparency as it is easier to recognize and identify potential issues (Bray, 1992).

For a small island like Malta, its economic diversification is of vital importance. Throughout the years, the Maltese economy was able to exceed in this area and excel its competitiveness in various sectors such as tourism, pharmaceuticals, gaming, and financial services. Malta is considered as one of the highest providers of vocational training in the European Union (EU), both in terms of time employed as well as in financial investments" (Malta Enterprise, 2018, p.57).

Eurostat in 2018 reports that $73 \%$ of Maltese enterprises each having ten or more employees have provided vocational training to their staff in 2015. In comparison, leading countries such as Sweden (93.1\%), Czech Republic (90.6\%) and Austria $(88.1 \%)$ have been rated the highest in providing organisational training (Malta Enterprise, 2018, p. 57). In the EU 28, the average number of hours spent by participants towards vocational training is around 26 hours on an annual basis in 2015. This varied from one country to another having 14 hours per employee in the Czech Republic, 17.5 hours in Latvia, 18.5 hours in Slovakia, 45 hours in Estonia and 38 hours in Malta. With regards to costs, vocational training courses in Malta 
accounted for 2.1\% of the total labour costs in 2015 (Malta Enterprise, 2018, p. 57).

With this research we aim to explore the key factors that have a significant impact towards training effectiveness within the Maltese financial industry. It can help to generate knowledge and awareness towards organisational management, highlighting the importance of having a well-planned training and development structure provided to its employees.

\section{Research Questions}

We aim to answer the following research questions:

1. What are the factors that affect the effectiveness of training within the Maltese financial industry?

2. What is the relationship between training and employee performance?

3. Are the results of (1) and (2) above effected by the different demographics of participants in the survey?

\section{Methodology}

\subsection{Conceptual Framework}

Based on the preliminary review of literature and discussion with peers on employee training in the financial industry, we identified a list of propositions of factors that have an impact on training effectiveness. These propositions as suggested by Yin (2009) and Stake (1995) were used to investigate further their impact on training effectiveness within the Maltese financial industry. Based on these propositions, we have conducted two surveys with respondents: the first survey immediately after a training event and the second survey within one month after the courses. The results of the surveys allowed us to identify the main factors that have a significant impact towards training effectiveness. Based on the analysis of these factors, we develop a Training Effectiveness Model (TEM) and investigate how such factors of training effectiveness change given the demographic characteristics. Based on the results of the second survey we analyzed whether the training has led to a development in performance and created an Employee Performance Development Model (EPDM). This is followed by determining the relationship between the TEM and the EPDM. In doing so, this study creates an evaluation framework that will assist organisations to evaluate the effectiveness of training as specified by regulation.

\subsubsection{Training Needs Analysis}

Training Needs Analysis (TNA) is the procedure which identifies the training needs of an organisation, towards the improvement of employee job performance. It observes the existing employee's competence level, skill areas for improvement and solutions on how to reach such outcomes (Gould et al., 2004). Gould et al. (2004), maintains that TNA is the preliminary step as part of a cyclical procedure that 
contributes towards an organisation's overall training strategy (Ludwikowska, 2018). The cycle initiates an organised discussion with top management and team leads, to determine the desired organisational outcome and the needs of the targeted trainees. This will be followed by designing the course, delivering the content, and evaluating the overall training outcome (Gould et al., 2004).

According to Salas et al. (2012), the initial step towards a successful implementation of any training is to have a TNA. Top management are subject to carry out a thorough needs analysis to make sure that training objectives are in line with the requirements of the employees as well as those of the organisation (Mzimela and Chikandiwa, 2017).

However, Ludwikowska (2018) outlines that from a business perspective most training programs delivered to employees, are much more based on personal desires, rather than structured in line with the identified needs. Organisations do not know how to implement TNA properly and sufficiently or not implement it at all. She continues to note that organisations, see TNA as a cost-burden and timeconsuming. Anderson (1994) concluded that a complete approach to TNA is very unlikely. Organisations choose to take an easy way out and follow their own traditional procedures based on office politics and a mixture of internal and external forces.

The TNA provides an inquiry that enables the organisation to make decisions in terms of the required employee learning outcomes, training design, implementation, training evaluation and other organisational aspects that may affect training and its effectiveness. It is interesting to note that a TNA has the potential to recognise that training might not always be the best approach to improve performance deficiencies, and that a non-training approach might be a better solution (Salas et al., 2012, p. 81).

\subsubsection{Clearly Communicated Training Objectives and Expected Outcomes}

As part of the development of an employee's training, it is fundamental for the organisation to set true and realistic training objectives. Unfortunately, this phase is the most overlooked step in the entire training and development process. The training process should initiate by knowing the training objectives, which should be discussed during training development meetings. In doing so, one must ensure that these are set up with due diligence (Andriotis, 2017).

First and foremost, the organisation must clearly define the purpose of the training and to whom it will be addressed. Once this is established and agreed upon, it will be easier for training developers to determine the training objectives that are bound to deliver the expected outcomes. Nonetheless, the data gathering, and analysis stage of the training cycle will assist to establish the reasons why training needs to be delivered in the first place (Andriotis, 2017). The training outcomes are the measurable goals analysed following training. They determine whether the overall training strategy was successful and competent enough to attain the initial 
identified needs of the organisation and its employees. Ultimately, the main scope of training objectives is to bring together the training programme with its actual business results. By establishing well-defined and measurable training goals at the beginning of the training process, these will lead to the success of a training programme (Andriotis, 2017). Certain aspects of business performance will be positively affected when an effective programme is utilised. So, it is important to make sure that all learning objectives will result in increased performance (Andriotis, 2017).

\subsubsection{Trainee Characteristics}

Previous studies have shown that trainee characteristics, which can be either related to behaviour or to motivation, have a significant influence on the training outcome (Tziner et al., 2007). Trainee characteristic is defined as the participant's performance self-efficacy to make use of the imparted knowledge and skills gained from the training provided, to a real work-life situation (Noe and Schmitt, 1986). Some of the impacts categorised as trainee characteristics are self-efficacy, goal orientation, motivation, locus of control amongst others.

From the above list self-efficacy has been strongly identified as an impact towards both learning and transfer of training (Ford et al., 1998; Gist et al., 1991). Selfefficacy is defined as an "individual's general belief that they are able to change their performance when desired (Holton et al., 2000, p. 47). Studies prove that trainees with a high self-efficacy aim to perform better in their workplace and are more likely to apply the training received in their day-to-day job (Velada and Caetano, 2007).

\subsubsection{Training Design}

Literature indicated that there are various design factors in training that are fundamental towards instructional techniques and learning principles. Therefore, organisations should plan their training programmes by taking into consideration those factors that increase the possibility of transfer and ultimately maintain training effectiveness. Holton et al. (2000), observe that training effectiveness refers to the degree to which training has been planned and delivered in such a way that it gives the trainee the ability to transfer what has been learnt back to the dayto-day job.

Furthermore, Holton et al. (2000), add that an element of training effectiveness is the level to which training instructions congruent with the job requirements. Previous studies have shown that trainees are more likely to transfer the newly learned knowledge to their workplace, when they recognize that the training programme was designed and delivered in such a way that maximises their ability to transfer the training to the job (Velada and Caetano, 2007).

\subsubsection{Work Environment}

The employee's work environment is versatile, whereby employees perform their daily job (Profijt, 2015). The work environment as a concept, in comparison to 
trainee characteristics and training design, is relatively less investigated. However, various studies recognised that work environmental factors are also fundamental in the understanding of training transfer and effectiveness (Alvarez et al., 2004; Baldwin and Ford, 1988; Holton, 1996; Tannenbaum and Yuki, 1992).

Profijt (2015) observes that the work environment captures multiple features that come out to be effective for the transfer of knowledge. Such aspects include feedback and support from colleagues, top management and supervisor support, exchange of knowledge with colleagues, the ability of openness to change, opportunity to perform, time, resources and ultimately personal outcome (Profijt, 2015).

\subsubsection{Job Task Analysis}

The purpose of a job task analysis is to identify those individual training needs in relation to the employee's knowledge, skills, and abilities to perform their tasks efficiently. Despite that there are several job-task analysis systems in place, several organisations omit such procedure and ask their employees to identify what training they require (Salas et al., 2012, p. 82). Following the latter, Baddley and Longman (1978), argue that this is not highly effective as employees are not able to articulate what training they actually require. It is suggested that management together with their employees participate in the job task analysis and outline the critical tasks of the job and most importantly the desired knowledge, skills, and competencies of an employee. By identifying employee requirements through the TNA, one will ensure that the training received will be beneficial towards the trainee (Horton, 2016).

\subsubsection{Organisational Analysis}

An organisational analysis identifies the company's training priorities as well as determining if the organisation is well-prepared to receive and support the training. It continues to identify tasks and functions that will have an impact on the organisational success. Nonetheless, it determines those essential organisational competencies that are necessary to accomplish an overall learning strategic alignment (Tannenbaum, 2002). Driscoll (2003) identifies that a strategic approach helps an organisation to prioritise the training needs and allocate the required training resources. In doing so, those pressing organisational needs will be taken into perspective (Driscoll, 2003).

Unfortunately, some might not consider organisational analysis as significant towards training effectiveness. They would rather focus on training needs and implement programmes according to their existing mind-sets. However, studies have shown that to remain in competition, it is imperative that strategic assessments are reviewed annually so that a defined alignment between training requirements and organisational needs are met (Salas et al., 2012). According to Reed and Vakola (2006), a well-defined relationship between needs analysis and 
existing organisational plans lead to a successful strategic transformation.

\subsubsection{Person Analysis}

The final category as part of the TNA is the person analysis, which determines who requires training and in what area they need to be trained on (Tannenbaum and Yukl, 1992). Person analysis helps to identify those essential competencies as determined under the job-task analysis. In addition, such analysis verifies that the training being provided is targeted to the trainees by assessing those individual characteristics such as personality, motivation, and goal orientation to further develop the training further (Salas et al., 2012).

With the execution of a person analysis, one can discover various aspects on their employees. Such information provides the organisation with a holistic overview on what type of training is essential to meet the identified individual needs. A study carried out by Kubeck et al. (1996), proposed that age has a positive relationship with training time, but it has a negative relationship with training performance. As a result, a well-designed training approach would assist the older workforce, such as allocating more training time and developing training material specifically for their needs (Salas et al., 2012).

\subsection{The Surveys}

As noted above, and following the literature review, we identified five specific factor propositions: 1) Training Needs Analysis, 2) Clearly Communicated Training Objectives and Expected Outcomes, 3) Trainee Characteristics, 4) Training Design and 5) Work Environment. As per the latter, we built the conceptual framework around these five themes as suggested by Miles and Huberman, (1994) and Stake, (1995), who argued that "each proposition serves to focus the data collection, determine the direction and scope of the study and together with the propositions form the foundation for a conceptual framework". Furthermore, the conceptual framework is used to establish whether these factor propositions correspond with the effectiveness of training within the Maltese financial industry.

Given the nature of this study, whilst keeping the research questions in mind, we opted for a mixed-method approach (Creswell, 2014). After a thorough analysis to identify the appropriate mixed method designs for this study, we opted for observations transformed into case studies and self-administered questionnaires (Yin, 2009). We observed various training sessions delivered to participants working within the financial industry and had the opportunity to observe both classrooms based as well as online training sessions. During such observations, the behaviour, and activities of the participants, as well as that of the speaker, were noted in an unstructured manner, without following any form of checklist or a preset thought of mind. 
At the beginning of each session, we presented ourselves to the audience whilst explaining the importance of the study being carried out. We explained that the study will consist of two separate self-administered questionnaires. We built the first questionnaire based on the factor propositions identified from the literature review. In addition, to assess training evaluation, the first questionnaire followed the basis of the Kirkpatrick evaluation framework, Level 1 - Reaction. The statements captured the trainee's reaction to measure the extent to which participants found the training relevant and engaging towards their day-to-day job (Praslova, 2010). Herein, the training programme provided by organisations aims to accomplish the trainee's trust that overall, the training was a valuable experience. Level 1, reaction criteria measure the degree to which trainees found the training provided engaging and relevant to their jobs (Barqawi, 2018; Kirkpatrick Partners, 2016). Kirkpatrick defines this level as a measure of (internal) customer satisfaction (Kirkpatrick Partners, 2016). This type of data is collected by means of a questionnaire, which is often known as smile sheets. These surveys are carried out immediately after a training event by the respective trainees (Beaurem et al., 2009). Throughout this process, the trainers will establish the necessary standards to enhance the training programmes for future training events (Barqawi, 2018).

In the first section we asked for the course details, specifically the course name, the training service provider, the duration, the name of the speaker, the date attended and whether the training was subject to a fee. The second section was designed to collect the demographics of the participants. Respondents were asked to identify their gender, age, highest level of education attained, the industry sector they worked in, their occupational status, the type of employment and their current occupation. The third section was divided into the five main propositions, whereby each proposition contained four close-ended statements which related to this proposition and was derived from literature, to which the respondents had to rate their level of agreement. The authors opted for a five-point Likert scale ranging from 1 for "Strongly Disagree" to 5 for "Strongly Agree".

Within a month's time, the second questionnaire was sent by email to the attention of the same participants following the training received. The authors continued to assess training evaluation by building the second questionnaire based on the Kirkpatrick evaluation framework, Level 2 - Learning, Level 3 - Behaviour and Level 4 - Results. Level 2 determined whether participants acquired new knowledge, skills, or other attributes from the training. Level 3 moved on to capture the degree, to which participants applied what they had learned on their return to their workplace. Ultimately, Level 4 aspired to measure the degree to which the employee's performance had improved following the training received.

In section one and section two, we asked for the same details as presented in the first questionnaire. However, the third section was designed to capture the learning and behaviour of the employee as well as other results in the employee's performance following training. This section was divided into three headings 
specifically: Learning outcomes, Employee job-related behaviour and Results. Each section had several statements based on these headings, to which respondents had to rate their level of agreement based on a five-point Likert scale.

At the end of both questionnaires, an open-ended comment box was included to ensure the identification of other important factors which were not captured initially in the propositions. Participants could express any other matters, which they believe were relevant towards the effectiveness of training and employee performance, after the training delivered.

\subsection{Sampling Strategy}

According to the National Statistics Office (NSO) - The Labour Force Survey: Q2/2019 (September 2019), the number of employees working within the Financial and Insurance Activities, amounted to 11,632 people (NSO, 2019). To reach the sample size of this study, we contacted various training and financial institutions by email, following an online research through Facebook adverts. They also used the snowballing sampling method, whereby participants suggested other training institutions and companies that offered training courses to the financial industry. We attended and observed five classroom-based courses and another 10 online training sessions being delivered to the individuals working within the financial industry (Table 1).

During the data collection, the rapid outbreak of the coronavirus hit the Maltese islands. Following the health authority measures, training sessions were no longer permissible to be delivered within a classroom-based environment. In this regard, we found an alternative to continue collecting data, whereby we opted for online training and used other social media such as Facebook and LinkedIn to capture some other responses. We applied this concept to continue sampling until we sensed that we had reached saturation (Guest et al., 2006; Mason, 2010; Morse, 1995), meaning that new participants would not add value (Saunders et al., 2007, p. 212). To increase the response rate, the authors also used the snowball sampling method. Despite it being a judgmental sampling, the authors believed that this was the best approach to obtain a broad range of responses from other employees currently working within the financial industry, to participate in the study.

Table 1. Training Sessions Attended

\begin{tabular}{|l|l|l|l|}
\hline $\begin{array}{l}\text { Date of } \begin{array}{l}\text { Course in } \\
2020\end{array} \\
\text { 28th } \\
\text { February }\end{array}$ & $\begin{array}{l}\text { Type of } \\
\text { Training }\end{array}$ & $\begin{array}{l}\text { Number of } \\
\text { Attendees }\end{array}$ & Type of Training Method \\
\hline 4th March & Classroom & 50 & Lecture Style - Power Point Presentation \\
\hline 9th March & Classroom & 28 & Lecture Style - Power Point Presentation \\
\hline 10th March & Classroom & 5 & Lecture Style/ Group Discussion \\
\hline 12th March & Classroom & 30 & Lecture Style - Power Point Presentation \\
\hline 26th March & Online & 45 & Live Lecture Style - Power Point Presentation \\
\hline
\end{tabular}




\begin{tabular}{|l|l|l|l|}
\hline 27th March & Online & 62 & $\begin{array}{l}\text { Live Lecture Style - Power Point Presentation \& } \\
\text { Whiteboard Function }\end{array}$ \\
\hline 28th March & Online & 43 & $\begin{array}{l}\text { Live Lecture Style - Power Point Presentation \& } \\
\text { Whiteboard Function }\end{array}$ \\
\hline 1st April & Online & 36 & $\begin{array}{l}\text { Live Lecture Style - Power Point Presentation \& } \\
\text { Whiteboard Function }\end{array}$ \\
\hline 2nd April & Online & 33 & Live Lecture Style - Power Point Presentation \\
\hline 7th April & Online & 45 & $\begin{array}{l}\text { Live Lecture Style - Power Point Presentation, } \\
\text { Group Discussion }\end{array}$ \\
\hline 14th April & Online & 28 & $\begin{array}{l}\text { Live Lecture Style - Power Point Presentation, } \\
\text { Visuals (videos) }\end{array}$ \\
\hline 17th April & Online & 16 & Live Lecture Style - Power Point Presentation \\
\hline 29th April & Online & 27 & Live Lecture Style - Power Point Presentation \\
\hline 7th May & Online & 45 & Live Lecture Style - Power Point Presentation \\
\hline
\end{tabular}

Source: Own study.

In order to ensure a significant sample size, the authors made use of an online sample size calculator. With the use of the following online tool https://www.surveysystem.com/sscalc.htm, at a 95\% confidence level with a 5\% confidence interval, it was determined that a sample size of 372 participants was required. Keeping this in mind, we had to ensure that at least 372 participants answered both first and second questionnaires. Despite the challenges encountered during this period (COVID-19), we achieved a sample of 383 participants.

\subsection{Data Collection}

Prior to the data collection used for this study, we conducted a pilot study as suggested by Yin (2009). This was conducted with around 15 attendees providing us with the opportunity to develop and refine the data content and data collection plans before commencing the official study. For the case studies, we collected data by observing both classroom-based and online sessions and noted down any behaviour, which they believed would add value for this study. We then distributed questionnaires both physically and online through a link using 'Qualtrix XM', to be self-administered by the attendees.

\subsection{Data Analysis}

For the two questionnaires, we used SPSS version 20 to analyse the descriptive statistics in Section 3, for the first questionnaire and sections 1, 2 and 3 in the second questionnaire. The respondent's data was analysed using 'exploratory factor analysis' to describe the relationship of training effectiveness as posed in the research questions involving variables in terms of a few underlying, but unobservable, random quantities called proposition factors (Yong and Sean, 2013). In this case the TEM did not have an apriori fixed number of factors. In addition, the comment boxes at the end of the self-administered questionnaires were analysed using the thematic approach as adapted by Braun and Clarke (2006). 


\subsection{Exploratory Factor Analysis}

For the first and second questionnaire, the factor validity and the identification of any possible structure that underlies the data was assessed by carrying out Exploratory Factor Analysis (EFA), using principal axis factoring extraction, with the Kaiser-Mayer- Olkin index (KMO) and Bartlett's test for sphericity to verify the adequacy of the sample and procedure respectively (Yong and Sean, 2013). The Varimax rotation was used in the application (Gorsuch, 1983). Proceeding with the preliminary analysis, following the practical considerations in performing an EFA, the correlation matrix was investigated. Since the observed variables are measured on a five-point Likert scale, the non-parametric version of the Pearson product-moment correlation, Kendall-Tau correlation, was used for both selfadministered questionnaires, respectively.

From the resulting correlation matrix, it was noticed that there is no correlation which may be large (higher than 0.8) already indicating that there should not be a problem of multicollinearity and singularity of the correlation matrix. Apart from that, in spite of some correlation coefficients being of a smaller absolute value than others, the majority of the coefficients obtained were significant at a 0.05 level of significance showing that there was enough evidence to reject the null hypothesis of no linear relationship. Moreover, the determinant of the correlation matrix resulted greater than 0.00001 , implying that there were no multicollinearity or singularity problems in the data.

The Bartlett's test of sphericity and the KMO measure of sampling adequacy for the first and second self-administered questionnaires as follows resulted significant $(<0.001)$ and $88.3 \%$ and $93.9 \%$ respectively. Since both are greater than 0.5 , the partial correlations for the variables in the data were significantly small (Kaiser, 1974). As a result, the existing correlation should be due to groupings in the variables. Therefore, factor analysis should have yielded some clearly specified factors. A p-value less than 0.0005 from the Bartlett's test of sphericity indicates that there is enough evidence to declare that the correlation matrix is significantly different from the identity matrix. Hence the appropriateness of using factor analysis on this dataset.

We carried out the Mann-Whitney test (a non-parametric analogue to independent samples t-test) to determine whether there are any disparities between two groups on a continuous or ordinal variable. We carried out the Kruskal-Wallis test (a nonparametric analogue to One-Way ANOVA) to determine whether there are any differences between three or more groups on a continuous or ordinal variable. (McDonald, 2009).

\subsection{Reliability and Validity}

We checked the internal consistency (reliability) of the self-administered questionnaires using the Cronbach's Alpha for each factor (Tavakol and Dennick, 
2011). Each factor from the first self-administered questionnaire, has overall achieved a good internal consistency, except for Factor 5, with a Cronbach's Alpha of 0.434. However, this was expected given the low factor loading for statement 3.4 in the factor analysis. It was therefore decided to remove statement 3.4 and conduct Cronbach's alpha again. In fact, with the removal of statement 3.4 , Cronbach's alpha value increased to 0.734 from 0.434 . The results are shown in Table 2.

Table 2. Cronbach's Alpha Value - First self-administered questionnaire

\begin{tabular}{|c|c|c|}
\hline Factor & Item & Cronbach's Alpha \\
\hline 1 & 7 & 0.869 \\
\hline 2 & 5 & 0.749 \\
\hline 3 & 3 & 0.774 \\
\hline 4 & 2 & 0.793 \\
\hline 5 & 2 & 0.734 \\
\hline
\end{tabular}

Source: Own study.

We then computed the TEM from these 5 factors and resultant 19 statements and carried out multiple linear regressions on the individual factors as well as on the TEM. This to determine how this measure varied with the demographic factor variables (RQ3) specifically namely: Gender; Age; Highest Level of Education Attained; Industry Sector you work in; Occupational Status; Type of Employment and Current Occupation.

Table 3. Cronbach's Alpha-Second self-administered questionnaire

\begin{tabular}{lll} 
Factor & Item & Cronbach's Alpha \\
\hline $\mathbf{1}$ & 13 & 0.944 \\
$\mathbf{2}$ & 2 & 0.601 \\
\hline
\end{tabular}

Source: Own study.

Table 3 illustrates the Cronbach's alpha for the second self-administered questionnaire. It shows that Factor 1 achieved an excellent internal consistency and Factor 2 obtained a fair internal consistency. Following the above, we then computed the EPDM from these 2 factors and 15 statements and carried out a correlation test to determine the relationship between the TEM and the EPDM.

\section{Results and Analysis}

\subsection{Sample Composition}

The survey questionnaire was answered by 383 respondents, who are all employees working within the financial industry. 208 respondents $(54.3 \%)$ were females, and 175 respondents $(45.7 \%)$ were males. Most of the participants were aged between 20 and 29 years old $(46.0 \%)$. These were followed by persons aged $30-39$ years $(23.8 \%)$, over 50 years $(14.9 \%), 40-49$ years $(14.1 \%)$ and with only $1.3 \%$ persons aged less than 20 . More than half of the participants attained tertiary 
level of education, of which 186 respondents (48.6\%) were post-graduate, 115 respondents $(30.0 \%)$ were undergraduate, and seven respondents $(1.8 \%)$ had a doctorate degree. Another 67 respondents (17.5\%) attended post-secondary education, with only eight respondents $(2.1 \%)$ having only who obtained only a school leaving certificate.

166 respondents $(43.3 \%)$ stated that they work within the insurance sector, followed by 66 respondents (17.2\%) working in accounts. On the other hand, 63 of the respondents (16.4\%) are working within the investment and advisory area and another 39 respondents (10.2\%) in the banking industry. Furthermore, 49 of the respondents $(12.8 \%)$ stated that they work in other sectors, such as the financial services regulation, ministry for finance, financial auditing, financial crime compliance and other financial services providers. A high proportion of the sample, with a head count of 335 respondents (87.5\%), are employees. Only 21 $(5.5 \%)$ and $27(7.0 \%)$ of the respondents claimed that they are self-employed with employees and without employees, respectively. Furthermore, most of the respondents (94\%) work on a full-time basis whereby the other 23 respondents (6.0\%) operate on a part-time basis. 133 respondents $(34.7 \%)$ claimed that they work as Professionals, 117 respondents $(30.5 \%)$ in a Clerical job and 101 respondents (26.4\%) in a Managerial occupation. Only five respondents (1.3\%) stated that they perform Manual work.

\subsection{Factors of Training Effectiveness (RQ1)}

Based on the consideration of extracting the number of factors according to the number of eigenvalues greater than one rule or close to one, 5 factors and 20 statements were extracted for the first self-administered questionnaire (see Table 4). The 5 interpretable factors generated; together explained $64.09 \%$ of the total variance. On the other hand, the second self-administered questionnaire extracted 2 factors and 15 statements. The two interpretable factors generated; together explained $62.95 \%$ of the total variance.

On trying to give a meaning to the factors extracted, Varimax rotated loadings provided a clearer picture for interpretation than the unrotated ones. All items loaded above 0.30 , with the exception for the first self-administered questionnaire, statement 3.4 - "in this course, my goal is to do better than other attendees without making any mistakes". Such statement was omitted as it explains little variance. Overall, as suggested by Cohen (1988), both self-administered questionnaires imply that there exists moderate to strong correlation between the factors and the original variables. Furthermore, there were no cross-loadings between the factors.

Therefore, TEM on European small states using factor analysis was supported with 5 factors and 19 statements. Table 4 shows the statements grouped under each of the 5 factors. Factor 1, which has now been termed "Training design, clear training objectives and its expected outcomes", explained $16.53 \%$ of the variance, and grouped seven statements. Factor 2 termed as "Work Environment and Self- 
efficacy" accounted for $13.31 \%$ of the variance and grouped five statements. Factor 3 named as "Training Needs Analysis \& Design" accounted for 9.95\% of the variance and grouped three statements. Factor 4 which has been termed as "Top Management Support" accounted for $7.13 \%$ of the variance and grouped two statements. Finally, Factor 5, which has now been termed as "Trainee Characteristics" accounted for $5.99 \%$ of the variance, and grouped three statements (Hair et al., 1998).

\section{Table 4. TEM -Rotated Factor Matrix ${ }^{a}$}

\begin{tabular}{|c|c|c|c|c|c|}
\hline & \multicolumn{5}{|c|}{ Factors } \\
\hline & 1 & 2 & 3 & 4 & 5 \\
\hline owledgeable and competent in the subject & .777 & .341 & -.050 & .058 & .040 \\
\hline $\begin{array}{l}2.3 \text { The trainer has met the objectives as outlined in the training } \\
\text { programme }\end{array}$ & .724 & .092 & .391 & -.001 & .167 \\
\hline $\begin{array}{l}\text { eoretical and } \\
\text { se }\end{array}$ & .669 & .155 & .107 & 107 & .054 \\
\hline ed with the educational level received from this & .625 & .133 & .521 & -.080 & .110 \\
\hline g methodology tools used were appropriate & .587 & .309 & .327 & & -.035 \\
\hline $\begin{array}{l}\text { cated for participants to discuss any } \\
\text { subject }\end{array}$ & .549 & .082 & .201 & -.009 & 238 \\
\hline $\begin{array}{l}2.1 \text { A detailed description of the training course and its } \\
\text { objectives were provided }\end{array}$ & .452 & .159 & .366 & .044 & .163 \\
\hline $\begin{array}{l}5.4 \text { I strongly believe that training is an ongoing process } \\
\text { requirement }\end{array}$ & .246 & .641 & .066 & -.024 & .256 \\
\hline $\begin{array}{l}\text { lee I have full readiness to perform this training } \\
\text { day-to-day job }\end{array}$ & .096 & .59 & .266 & .130 & .028 \\
\hline $\begin{array}{l}5.3 \text { Knowledge and skills acquisition are part of my job } \\
\text { responsibilities }\end{array}$ & .122 & .570 & .172 & .045 & .155 \\
\hline myself confident and willing to learn more & .251 & .552 & .077 & 24 & .520 \\
\hline $\begin{array}{l}\text { to attend } \\
\text { e }\end{array}$ & .10 & 17 & .05 & .141 & .05 \\
\hline rse, my job & .20 & .240 & .675 & .240 & .091 \\
\hline my individual objectives and & .327 & .154 & .641 & .132 & .100 \\
\hline tt was relevant in line with my job needs & .234 & .478 & 82 & 01 & .101 \\
\hline $\begin{array}{l}1.1 \mathrm{I} \text { a } \\
\text { needs }\end{array}$ & .039 & .093 & .068 & .844 & .072 \\
\hline $\begin{array}{l}1.2 \text { In discussion with my seniors, I selected this course as it } \\
\text { seems the appropriate training course to achieve the required } \\
\text { competencies }\end{array}$ & .070 & .162 & .170 & .730 & .072 \\
\hline $\begin{array}{l}3.2 \text { When I attend training courses, I try to learn as much as I } \\
\text { can to improve my knowledge and perform better in my day-to- } \\
\text { day job }\end{array}$ & .280 & .490 & .151 & .046 & .617 \\
\hline $\begin{array}{l}3.3 \text { I like to attend training cour } \\
\text { make me think }\end{array}$ & .207 & .426 & .038 & .039 & .509 \\
\hline $\begin{array}{l}3.4 \text { In th } \\
\text { without }\end{array}$ & -.001 & -.001 & .017 & .126 & .161 \\
\hline
\end{tabular}


a. Rotation converged in 18 iterations.

Source: Own study.

\subsection{The Factors of the Employee Performance Development Model - (RQ2)}

The EPDM Exploratory Factor Analysis was supported with 2 factors and 15 statements. Table 5 shows the statements grouped under each of the two factors. Factor 1, which has now been termed "Evaluation and Results", explained 50.1\% of the variance, and grouped 13 statements, whilst Factor 2 termed as "Support and Clarification", accounted for $6.37 \%$ of the variance, and grouped two statements (Hair et al., 1998).

Table 5. EPDM Rotated Component Matrix ${ }^{a}$

\begin{tabular}{l|l|l} 
& \multicolumn{2}{l}{ Factors } \\
\hline $\begin{array}{l}\text { 2.2 Following this training course, I am making smarter decisions faster } \\
\text { 2.3 I feel that I am now performing better in my work, than prior to training }\end{array}$ & $\mathbf{. 8 7 1}$ & -.104 \\
\hline $\begin{array}{l}\text { 3.3 Following this training, clients/management are pleased with the efficiency and } \\
\text { improvements I am making in my daily work activities }\end{array}$ &.- .135 \\
\hline $\begin{array}{l}\text { 2.1 I have used the training content learned into my daily work } \\
\text { 1.3 I feel that I can apply what I have learnt to overcome challenging situations at } \\
\text { work }\end{array}$ &.- .011 \\
3.1 My employee performance has increased as a result of my attendance to this \\
training course
\end{tabular}

Extraction Method: Principal Component Analysis.

Rotation Method: Varimax with Kaiser Normalization.

a. Rotation converged in 3 iterations.

Source: Own study. 
On trying to give a meaning to the factors extracted, Varimax rotated loadings provided a clearer picture for interpretation than the unrotated ones. All items loaded above 0.30 , with the exception for the first self-administered questionnaire, statement 3.4 - "in this course, my goal is to do better than other attendees without making any mistakes". Such statement was omitted as it explains little variance.

Overall, as suggested by Cohen (1988), both self-administered questionnaires imply that there exists moderate to strong correlation between the factors and the original variables. Furthermore, there were no cross-loadings between the factors.

\subsection{The Evolvement of the Individual Factors affecting the Effectiveness of Training with different Demographic Characteristics - (RQ3)}

Furthermore, we explore the evolvement of the individual factors affecting the effectiveness of training (as dependent variables) with different demographic characteristics (independent variables). The Mann-Whitney and the KruskalWallis tests were used to check whether the distribution of scores of each factor differed by each demographic variable. The Mann-Whitney test revealed that there are no significant differences in the distribution of each factor mean score between males and females except for Factor 3, Training Needs Analysis (TNA) and Design $(\mathrm{p}$-value $=0.032)$ and Factor 5, Trainee Characteristics ( $\mathrm{p}$-value $=$ 0.048) (Appendix II). In GLM, Gender also resulted to be a significant predictor for Factor 3. On the other hand, for Factor 5, it was not significant. In fact, looking at the value of the p-value from the Mann-Whitney Test, one can expect this as it is almost 0.05. Appendix I shows that for Factor 3, the mean score for males (3.89) is less than for their female counterpart (4.06). This implies that females tend to agree more with the statements of Training Needs Analysis (TNA) and Design, whilst males had a more neutral response. For Factor 5, the mean score for males (4.55) is slightly greater than their female counterpart (4.43). As a result, both genders agreed with the statements of Trainee Characteristics.

TNA is the initial step towards the successful implementation of any training. Results have shown that training needs analysis and its design have a significant impact on the training outcome when gender is investigated. Very often organisations develop and implement training without first conducting a TNA. As a result, if one ignores such analysis, training effectiveness and employee performance will be affected. The result obtained is consistent with that illustrated by Chou (2001), whereby such study concluded that gender turned out to be a significant moderator that influenced the training method used. Furthermore, a study carried out by Weiss et al. (2003), concluded that women tend to perform better on verbal tasks, while men surpass women on visual-spatial tasks. Additionally, another interesting result shows that men experience a higher level of self-efficacy than women during the training course. It indicates that men are ambitious to attend training courses, which are challenging and make them think, whilst aspiring to do better than the other attendees. 


\subsection{Thematic Analysis}

Based on the observations of both classroom-based and online sessions, we have conducted a case study to note down any behaviour, which would add value for this study. Table 6 shows thematic analyses for the themes corresponding to the observations.

Table 6. Thematic Analysis for the Themes Corresponding to the Observations

\begin{tabular}{|c|c|}
\hline Themes & Description \\
\hline $\begin{array}{l}\text { Clear training } \\
\text { objectives and } \\
\text { expected outcomes }\end{array}$ & $\begin{array}{l}\text { Trainers initiated their session by introducing the subject being delivered. One } \\
\text { clearly explained the training objectives and its expected outcomes. Well- } \\
\text { defined training objectives and outcomes offer a framework for trainers to } \\
\text { organise relevant training material and eliminate unnecessary content. } \\
\text { Nonetheless, clear objectives and outcomes help trainees to review the training } \\
\text { programme and ensure that their established training goals are reached. As result, } \\
\text { trainees start to appreciate that their work and training objectives are linear to } \\
\text { one another. This increases the trainee's motivation leading to a better outcome } \\
\text { on their job performance. }\end{array}$ \\
\hline Smaller is better & $\begin{array}{l}\text { Very often, large sized training sessions are targeted at maximising attendance } \\
\text { that helps to reduce administration expenses and any other related costs. By } \\
\text { having a larger scale of attendees, one expects to have more distractions and } \\
\text { participation is very low. Furthermore, there is no doubt that trainees lose focus } \\
\text { at some point in time during the session. Whilst observing a small group of } \\
\text { around } 15 \text { attendees, the authors could note that this creates an informal } \\
\text { environment whereby active participation, cross sharing experiences and } \\
\text { problem solving brings about flexibility in learning. The trainer can get to know } \\
\text { each of their trainees personally. As a result, the trainer would be able to develop } \\
\text { and teach in a way that will work towards their understanding. Trainees feel } \\
\text { comfortable in joining conversations, which aspires others to participate. } \\
\text { Furthermore, in a small group, trainers are more likely to gather feedback, which } \\
\text { helps in identifying whether the training objectives are met. }\end{array}$ \\
\hline $\begin{array}{l}\text { Trainee } \\
\text { participation }\end{array}$ & $\begin{array}{l}\text { During classroom-based sessions, it was felt that it can be intimidating for } \\
\text { trainees to raise their hand in a class to ask a question. Furthermore, one's } \\
\text { shrinking attention span demands that trainers create content that keeps the } \\
\text { trainees engaged. Interactive training provides an immersive and engaging } \\
\text { learning experience for the trainees. This can be achieved by informing } \\
\text { beforehand that there will be pop-up questions. This encourages trainees to pay } \\
\text { attention and makes them more receptive to the information. Through online } \\
\text { observations, trainee participation was stronger in comparison to classroom- } \\
\text { based sessions. Some of the trainers prepared three or four short questions, } \\
\text { whereby the trainee could simply reply through the chat box with a short answer, } \\
\text { such as a 'Yes' or 'No'. This ensured a highly engaging user experience that } \\
\text { enhanced the effectiveness of training being delivered. }\end{array}$ \\
\hline $\begin{array}{l}\text { Sessions not } \\
\text { longer than three } \\
\text { hours }\end{array}$ & $\begin{array}{l}\text { The challenge for every trainer is to deliver the right training at the right time. } \\
\text { Long sessions of four hours or more felt that the timing did not coincide with the } \\
\text { trainee's opportunity to apply what has been learnt back on the job. Trainees } \\
\text { started to lose their motivation in the session. During such observations, the } \\
\text { authors saw that having training courses split into shorter modules will lead to } \\
\text { an improved and effective learning outcome. Moreover, providing multiple } \\
\text { breaks during the session can also help the trainees to refresh. This is why it is } \\
\text { important to conduct a training needs analysis, to establish the right duration, the } \\
\text { relevant content that adds value and eliminate any unnecessary information. }\end{array}$ \\
\hline
\end{tabular}




\begin{tabular}{|c|c|}
\hline $\begin{array}{l}\text { Colour scheme } \\
\text { presentations }\end{array}$ & $\begin{array}{l}\text { Throughout the observations, only one trainer used the colour scheme theory for } \\
\text { the presentation. The authors could note that the use of colours helped in } \\
\text { reducing boredom and passivity, thus improving the trainees' attention spans. } \\
\text { Red tends to stand out and grabs attention, which helps the trainees to remember } \\
\text { facts and figures. The use of colour can enhance clarity and readability, which } \\
\text { automatically makes concepts more logical and helps with the reasoning and } \\
\text { memory of the trainee. Literature shows that people tend to remember colours } \\
\text { more than verbal or text on its own. The authors suggest that by adopting such } \\
\text { an approach, trainers become a better visual communicator to their audience. } \\
\text { One should keep in mind that too many colours lead to cognitive overload and } \\
\text { become counter-productive. }\end{array}$ \\
\hline Native Language & $\begin{array}{l}\text { Despite that Malta has two official languages, Maltese and English, the authors } \\
\text { could note that those sessions delivered in Maltese had better trainee } \\
\text { engagement. Certain terms were more easily understood in Maltese rather than } \\
\text { in English by the trainees. However, given that we are living in a multi-national } \\
\text { country, one cannot simply deliver a full session in Maltese. In such case, one } \\
\text { should deliver the session in English but define certain technical terms in } \\
\text { Maltese, where applicable. Training delivered in the trainee's native language } \\
\text { increases comprehension and helps the trainee in the transfer to the job. }\end{array}$ \\
\hline $\begin{array}{l}\text { The use of mobile } \\
\text { phones and mobile } \\
\text { learning }\end{array}$ & $\begin{array}{l}\text { The use of mobile phones during training sessions can be distracting for both the } \\
\text { trainer and trainees. A good way to combat the ineffective use of mobile phones } \\
\text { is to introduce mobile learning. The use of smart phones during training sessions } \\
\text { adds a new level of connectivity between the trainer and the trainees. By using } \\
\text { activities like interactive info graphics, quizzes, sharing of documents, feedback } \\
\text { gathering and videos, trainees become more motivated and engaged with the } \\
\text { training material. One should take note that no matter how fun the content is, } \\
\text { trainees will not engage if the learning resources are not easy to navigate on a } \\
\text { mobile device. Overall, this can be seen as a social platform that motivates } \\
\text { trainees whilst connecting them with like-minded people. }\end{array}$ \\
\hline $\begin{array}{l}\text { Trainer's tone of } \\
\text { voice }\end{array}$ & $\begin{array}{l}\text { From the sessions observed, the tone of voice is highly important in achieving } \\
\text { training effectiveness. Through online training, trainees are unable to see the } \\
\text { trainer's body language. The wrong tone of voice can impact one's credibility } \\
\text { and professionalism. It is therefore fair to say that tone of voice is a major } \\
\text { contributor for both online and even classroom-based sessions. Throughout such } \\
\text { observations, a trainer's tone of voice sounds engaging when one allows his/her } \\
\text { voice to express their unique personality, transparency and passion towards the } \\
\text { subject being delivered. Nevertheless, without the speaker's affection and } \\
\text { warmth towards the audience, the delivery of the training session would still } \\
\text { sound dull. Sounding your best tends to improve engagement between the trainer } \\
\text { and trainee, which ultimately leads towards training effectiveness. }\end{array}$ \\
\hline
\end{tabular}

Source: Own study.

Table 7 presents the thematic analyses for themes corresponding to the comment box. It proves, that the authors' suggested propositions cover all important aspects of training effectiveness assessment. Appendix III illustrates that for Factors 1 and 2, the mean score for respondents aged less than 20 (4.09 and 3.84) is the lowest compared to respondents aged over 50 years (4.43 and 4.50). For Factor 3, the mean score for respondents aged 20 to 29 (4.03) is the lowest compared to respondents aged less than 20 (4.13) and over 50 (4.12). Appendix IV shows that a significant difference was only observed for three factors; Factor 1, Training Design, Clear Training Objectives and its Expected Outcomes ( $p$-value $=0.039$ ); Factor 2, Work Environment and Self-Efficacy (p-value $=0.001$ ) and Factor 3, Training Needs Analysis (TNA) and Design ( $\mathrm{p}$-value $=0.029$ ). No difference has 
been observed for the remaining factors taken as the factors of training effectiveness.

Table 7. Thematic Analysis for the Themes Corresponding to the Comment Box in the First Self-Administered Questionnaire

\begin{tabular}{|l|l|}
\hline Themes & Description \\
\hline $\begin{array}{l}\text { Training adjusted to the } \\
\text { employee's knowledge, } \\
\text { skills and ability }\end{array}$ & $\begin{array}{l}\text { Some of the participants felt that the training received was designed } \\
\text { to a 'one size fits all' approach. It was argued that courses should be } \\
\text { designed in line with the trainee's learning objectives, whereby } \\
\text { trainees would be grouped into clusters. Content is then designed and } \\
\text { delivered according to the needs of that cluster. }\end{array}$ \\
\hline $\begin{array}{l}\text { Sessions should be kept } \\
\text { short and simple }\end{array}$ & $\begin{array}{l}\text { Participants pointed out that some of the trainers had to deliver a lot } \\
\text { of information within a short period of time. Furthermore, } \\
\text { presentations were overloaded with text which made it even more } \\
\text { difficult for the trainee to digest all the information. Despite that some } \\
\text { of the sessions took around four hours, trainees argued that it would } \\
\text { have been better to have multiple sessions split into a shorter duration. } \\
\text { This enables the trainee to focus and understand better the content } \\
\text { being delivered. A participant also pointed out that it would be a good } \\
\text { idea to have the notes available before the session, so that they can } \\
\text { familiarise themselves with the content. }\end{array}$ \\
\hline $\begin{array}{l}\text { "I attended this course to to } \\
\text { make up for the hours" }\end{array}$ & $\begin{array}{l}\text { It was noted that some of the participants have attended such training } \\
\text { courses simply to make up for their CPD hours, as illustrated by the } \\
\text { regulation currently in place for the financial industry. This was a } \\
\text { disappointing factor, as trainees are not realising the importance of } \\
\text { such training and development for their day-to-day job. Furthermore, } \\
\text { trainees are not finding the training relevant and interesting which } \\
\text { lessens the motivation even further. For this reason, trainers should } \\
\text { always emphasise the importance of the training being delivered and } \\
\text { clearly define the learning objectives. In this way, trainees can put } \\
\text { their mind into perspective and focus on the relevance of the training, } \\
\text { to improve their knowledge and employee performance. }\end{array}$ \\
\hline
\end{tabular}

Source: Own study.

Studies have shown that age-related differences in training performance typically affect the training outcome. Given that it is now somewhat outdated, the definitive source on age and its impact on training is that as outlined by Kubeck et al. (1996). Such study indicated that the older the trainees, the less the mastery of the training content. More mature trainees require more time to fully understand the content being delivered. Furthermore, the age effect on training effectiveness is to be taken into consideration because of slower processing speed and reduced working memory capacity. In addition, as outlined by Chen et al. (2006) when information technology is introduced, through the means of e-learning, there is a tendency that older trainees find it more challenging to adopt to such a virtual environment. Some might feel more comfortable with the normal classroom- based session. Therefore, it might be beneficial for the organisation to pre-train older trainees on how to improve their computer skills, to achieve a better learning outcome.

Furthermore, the training objectives and one's learning outcomes might not be the same for everyone. It could be the case that a younger trainee's learning outcomes 
might be more challenging than that of a mature trainee who has more work experience in the subject area, who does not have the same level of accomplishment at the end of the training. This goes in line with the finding of Thijssen (1996), cited by Van der Klink et al. (2001), implying that older trainees with various working experiences tend to have fewer problems in achieving the training goals.

The working environment and self-efficacy factor investigated with age brings about several interesting outcomes towards its effectiveness on training. To begin with, motivation to learn is a high state of arousal that has an impact towards training effectiveness, but as they say charity begins at home. If trainees are not supported by their place of work, employees will start to feel unaccompanied and de-motivated. Rothe et al. (2012) denote that the younger generation are more inclined towards a working environment that supports joint effort, social interactions, and novelty within an organisation. In contrast, the older generation prefer to have networking possibilities with other groups within the organisation. Consequently, self-efficacy will start to diminish if one feels as not being recognised in his/her working environment. Ultimately, if the employee is not satisfied with the surrounding working environment, the trainee feels ineffectual in achieving the learning outcomes. Studies have shown that with advancing age, additional factors may begin to influence self-efficacy (Levy, 1996; Levy et al., 2002). Therefore, with a well-established working environment, employees will feel motivated, self-efficacy will improve, which will ultimately result into a positive training outcome, irrespective of one's age.

As outlined by Mzimela and Chikandiwa (2017) top management are subject to carry out a thorough TNA to ensure that training objectives are in line with the objectives of the employees as well as that of the organisation. Two main categories of TNA are, job task analysis and person analysis, whereby through such analysis one will identify those who need training, and what kind of training is required. As noted above, there is the tendency that older trainees, will on average, learn less than younger trainees due to cognitive abilities and motivation. To combat such issues, it is suggested that training is designed in line with the person's needs and abilities. For instance, older trainees may be provided with training that is designed to limit cognitive limitations. This goes in line with that suggested by Sharit et al. (2009) whereby training content could be presented at a slower rate, with smaller chunks of information to lessening the effects of slower processing speed and reduced working memory.

Furthermore, as analysed during such observations, the use of colour theory might also help trainees to remember the concept even further through visual memory. On the contrary, Van Gerven et al. (2006) argue that there is no need to have such specific training designed to older trainees. If organisations take into consideration a well-designed training, both young and mature trainees will benefit from the training being delivered (Van Gerven et al., 2006). 
The Kruskal Wallis test revealed that there are no significant differences in the distribution of each factor between industry sectors except for Factor 1, Training Design, Clear Training Objectives, and its Expected Outcomes, with a p-value that is equal to 0.047. The mean scores whereby the 'Investments and Advisory' sector and 'Other' tend to have the highest mean score (4.61), whilst the lowest mean score was represented by the Accounting Sector (4.33). Overall, the participants agreed with statements found under Factor 1 (Appendix V and Appendix VI).

A well-designed training programme shall cater for the training needs of the employees to reach the learning outcomes as required by the industry. Such analysis might be significant for Factor 1, because some of the courses were designed to feature as part of the accreditation for CPD that is applicable to the financial industry.

During such observations, several trainees mentioned that due to the constant pressure to make up for their CPD hours, one might have simply attended a training course without evaluating their personal learning outcomes and hence find the training as irrelevant or not reaching their expected outcomes.

Therefore, it is important that trainees clearly evaluate the training outcomes and see their relevance to their job, prior to attending the course. This shall also be in communication with top management to provide the required training resources in line with the employee's training needs. This corroborated with what was illustrated by Reed and Vakola (2006), whereby a well-defined relationship between needs analysis and existing organisational plans lead to a strategic organisational transformation. Ultimately, the training design must always cater for the needs as identified during the TNA.

A significant difference was only observed for two factors: Training Design, Clear Training Objectives, and its Expected Outcomes ( $\mathrm{p}$-value $=0.016$ ), and Top Management Support ( $\mathrm{p}$-value $=0.038$ ). No difference has been observed for the remaining factors taken as the factors of training effectiveness. Respondents who stated that their current occupation is 'Other' resulted to have the highest mean score for all factors (Appendix VII and Appendix VIII).

Job task analysis outlines the critical tasks of the job as well as the required competencies of the employee within the organisation. As a result, the training design and the learning outcomes differ from an employee having a manual occupation to an employee having a professional occupation. Consequently, the training objectives and learning outcomes should be aligned with an employee's position, competency profile as well as to the organisation's business goals (Table 18). As already noted above, previous studies found that self-efficacy and motivation are positively related to the employee's performance (Çetin and Askun, 2018). There is a tendency that the higher the level of occupation the higher the level of achievement towards the organisation. It is important to note that every 
occupation within the organisation brings its own accomplishment and performance goals. Top management need to support and appreciate every effort made by the employees throughout the organisation and not only those at the top level. When employees feel appreciated, the motivation to learn is increased and hence this will show in their job performance, leading to an overall organisational success.

\section{Conclusion}

Enhanced knowledge, skills and capabilities are the significant elements in the achievement of an organisation's competitive advantage within today's global market. To achieve that competitive element, organisations should invest in the training and development of their employees.

The study has shown that training needs analysis, clear training objectives and expected outcomes, trainee characteristics, training design and work environment are the main factors of a strategic and effective employee training. Besides, are no significant differences in the distribution of each factor mean score between males and females except for training needs analysis and design, and trainee characteristics.

An effective training is a prerequisite, but it will not be successful unless an organisation evaluates the learning outcomes. Organisations need to ensure that the training courses are aligned to the employee's and the organisation's goals and objectives. With this study, the authors shed light that with an effective training in place, organisations can benefit from an improved employee performance leading to an overall organisational success. By adopting the above framework, management will ensure that effective training is received and sustained by their workforce.

\section{References:}

Alvarez, K., Salas, E., Garofano, C.M. 2004. An integrated model of training evaluation and effectiveness. Human Resource Development Review, 3(4), 385-416.

Andriotis, N. 2018. 5 Reasons Managers Should Improve Employee Engagement and Training. Retrieved from https://www.efrontlearning.com/blog/2018/05/whymanagers-improve-employee-engagement-training.html

Baddeley, A.D., Longman, D.J.A. 1978. The influence of length and frequency of training session on the rate of learning to type. Ergonomics, 21(8), 627-635. doi:10.1080/00140137808931764.

Baldwin, T. T., Ford, J.K. 1988. Transfer of training: A review and directions for future research. Personnel Psychology, 41(1), 63-105.

Barqawi, M. 2018. Kirkpatrick's Four-Level Training Evaluation Model. Retrieved from https://www.slideshare.net/Maram_barqawi/kirkpatricks-fourlevel-trainingevaluation-model.

Beaurem, D., Kacin, S., Megill, J., Palmisano, J., Siko, J. 2009. Kirkpatrick's Four Levels of Evaluation Model. 
Retrieved from: https://www.slideshare.net/sikojp/kirkpatricks-four-levels-ofevaluation-model.

Bezzina, F., Grima, S., Mamo, J. 2014. Risk management practices adopted by financial firms in Malta. Managerial Finance, 40(6), 587-612. doi:10.1108/MF08-2013-0209.

Braun, V., Clarke, V. 2006. Using thematic analysis in psychology. Qualitative Research in Psychology, 3(2), 77-101.

Bray, M. 1992. Educational Planning in Small Countries. France: UNESCO.

Briguglio, L. 1995. Small island developing states and their economic vulnerabilities. World Development, 23(9), 1615-1632.

Carabott, S. 2019. Maltese researchers develop less invasive and improved cancer screening. Times of Malta.

Retrieved from https://timesofmalta.com/.

Çetin, F., Aşkun, D. 2018. The effect of occupational self-efficacy on work performance through intrinsic work motivation. Management Research Review, 41(2), 186-201. doi:10.1108/MRR-03-2017-0062.

Chen, H., Holton, E., Bates, R.A. 2006. Situational and demographic influences on transfer system characteristics in organizations. Performance Improvement, Quarterly, 19(3), 7-25.

Cohen, J. 1988. Statistical power analysis for the behavioral sciences (2nd ed.). Hillsdale, NJ: Lawrence Earlbaum Associates.

Gould, D., Kelly, D., White, I., Chidgey, J. 2004. Training needs analysis. A literature review and reappraisal. Int J Nurs Stud., 41(5), 471-486. doi: 10.1016/j.ijnurstu.2003.12.003. PMID: 15120976.

Creswell, J.W. 2014. A concise introduction to mixed methods research. Thousand Oaks: SAGE publications.

Denby, S. 2010. The importance of training needs analysis. Industrial and Commercial Training, 42(3), 147-150. doi:10.1108/00197851011038132.

Driscoll, M. 2003. Whirlpool: Innovation and organizational learning. Chief Learning Officer, 2(2), 48.

European Parliamentary Research Service. 2019. How the EU Budget is Spent. Spending programmes under the 2014-2020 Multiannual Financial Framework. Members' Research Service PE 637.925 - April 2019. Retrieved from https://www.europarl.europa.eu/RegData/etudes/BRIE/2019/637925/EPRS_BRI( 2019)637925_EN.pdf

Ford, J.K., Smith, E.M., Weissbein, D.A., Gully, S.M., Salas, E. 1998. Relationships of goal orientation, metacognitive activity, and practice strategies with learning outcomes and transfer. Journal of Applied Psychology, 83(2), 218.

Foshay, W.R., Tinkey, P.T. 2007. Evaluating the effectiveness of training strategies: Performance goals and testing. ILAR Journal, 48(2), 156-162.

Gist, M.E., Stevens, C.K., Bavetta, A.G. 1991. Effects of self-efficacy and posttraining intervention on the acquisition and maintenance of complex interpersonal skills. Personnel Psychology, 44(4), 837-861.

Gorsuch, R.L. 1983. Factor analysis (second ed.). Hillsdale, New Jersey: Lawrence Erlbaum Associates, Inc. Publishers.

Guest, G., Bunce, A., Johnson, L. 2006. How many interviews are enough? An experiment with data saturation and variability. Field Methods, 18(1), 59-82.

Hair Jr., J.F., Anderson, R.E., Tatham, R.L., Black, W.C. 1998. Multivariate Data Analysis (5th ed.). Upper Saddle River, NJ: Prentice Hall.

Holton III, E.F. 1996. The flawed four-level evaluation model. Human 
Resource Development Quarterly, 7(1), 5-21.

Holton, III, E.F., Bates, R.A., Ruona, W.E. 2000. Development of a generalized learning transfer system inventory. Human Resource Development Quarterly, 11(4), 333360.

Horton, B.M. 2016. A risk management-based training decision framework: improving training outcomes. Unpublished doctoral Dissertation. Retrieved from University of Wollongong.

Jain, S. 2015. Cost-effectiveness of training programmes in insurance sector of India. Management Dynamics in the Knowledge Economy, 3(3), 533-551.

Kaiser, H.F. 1974. An index of factorial simplicity. Psychometrika, 39(1), 31-36.

King, R. 1993. The geographical fascination of islands. In: D.G. Lockhart, D. DrakakisSmith, J.A. Schembri (eds.). The Development Process in Small Island States. London, Routledge, 13-37.

Kirkpatrick Partners. 2016. The new world level 1 reaction sheets. Retrieved from https://www.kirkpatrickpartners.com/Portals/0/Storage/The\%20new\%20worl d\%20level\%201\%20reaction\%20sheets.pdf.

Kubeck, J.E., Delp, N.D., Haslett, T.K., McDaniel, M.A. 1996. Does job-related training performance decline with age? Psychology and Aging, 11(1), 92.

Kurniawati, F., De Boer, A.A., Minnaert, A., Mangunsong, F. 2017. Evaluating the effect of a teacher training programme on the primary teachers' attitudes, knowledge, and teaching strategies regarding special educational needs. Educational Psychology, 37(3), 287-297.

Levy, B. 1996. Improving memory in old age through implicit self-stereotyping. Journal of Personality and Social Psychology, 71(6), 1092.

Levy, B.R., Slade, M.D., Kasl, S.V. 2002. Longitudinal benefit of positive selfperceptions of aging on functional health. The Journals of Gerontology Series B: Psychological Sciences and Social Sciences, 57(5), 409-417.

Ludwikowska, K. 2018. The effectiveness of training needs analysis and its relation to employee efficiency. Zeszyty Naukowe Politechniki Poznańskiej.Organizacja i Zarządzanie, 77, 179-193. doi.org/10.21008/j.0239-9415.2018.077.11.

Lyons, P. 2008. Training for template creation: A performance improvement method. Journal of European Industrial Training, 32(6), 472-489.

Malta Enterprise. 2018. Training, Investment report doing business in Malta, 57-58. Malta: Malta Enterprise. Retrieved from

http://www.maltaenterprise.com/sites/default/files/Doing\%20Business\%20in\%20M alta.pdf.

Mason, M. 2010. Sample size and saturation in PhD studies using qualitative interviews.

Forum Qualitative Sozialforschung / Forum: Qualitative Social Research, 11(3), 1- 19.

McDonald, J.H. 2009. Handbook of biological statistics. Baltimore: Sparky house publishing.

Miles, M.B., Huberman, A.M. 1994. Qualitative data analysis: An expanded sourcebook. Thousand Oaks: Sage Publications.

Mohan, P., Strobl, E., Watson, P. 2018. In-firm training, innovation, and productivity: The case of Caribbean small island developing states. Entrepreneurship \& Regional Development, 30(9-10), 987-1011.

Morse, J.M. 1995. The significance of saturation. Qualitative Health Research, 5(3), 147 149. Retrieved from https://journals.sagepub.com/doi/pdf/10.1177/104973239500500201.

Mzimela, T., Chikandiwa, C.T. 2017. Employee training and development practices in the tourism and leisure sector in kwazulu-natal, South Africa. African Journal of 
Hospitality, Tourism and Leisure, 6(4), 1-17.

Nagar, V. 2009. Measuring training effectiveness. The Indian Journal of Commerce, 62(4), 86-90.

Nassazi, A. 2013. Effects of training on employee performance: evidence from Uganda.

Unpublished thesis. Vaasan Ammattikorkeakoulu University of Applied Sciences, Finland.

National Statistics Office. 2019. Labour force survey: Q2/2019. (157/2019), News Release.

Retrieved from https://nso.gov.mt/en/News_Releases/View by_Unit/Unit_C2/Labour_Mark et Statistics/Documents/2019/News2019 157.pdf.

Noe, R.A., Schmitt, N. 1986. The influence of trainee attitudes on training effectiveness: Test of a model. Personnel Psychology, 39(3), 497-523.

Petkova, Z.Y. 2011. Optimizing training effectiveness: The role of regulatory fit. Unpublished doctoral dissertation. University of Akron, United States. Retrieved from http://rave.ohiolink.edu/etdc/view?acc_num=akron1320673768.

Praslova, L. 2010. Adaptation of Kirkpatrick's four level model of training criteria to assessment of learning outcomes and program evaluation in higher education. Educational Assessment, Evaluation and Accountability, 22(3), 215225. doi:10.1007/s11092-010-9098-7.

Profijt, J. 2015. The influence of the work environment on training transfer. Unpublished Master Thesis. University of Twente, Netherlands.

Ramachandaran, R. 2010. Effectiveness of training programs of NLC-An analysis. Kegees. Journal of Social Science, 2(1), 119-129.

Rana, D. 2016. Assessing the impact of training design and development on employees' performance insurance sector in kingdom of Saudi Arabia. International Journal of Management Sciences and Business Research, 5(12), 251-260.

Reed, J., Vakola, M. 2006. What role can a training needs analysis play in organisational change? Journal of Organizational Change Management, 19(3), 393-407.

Rodriguez, J., Walters, K. 2017. The importance of training and development in employee performance and evaluation. Worldwide Journal of Multidisciplinary Research and Development, 3(10), 206-212.

Rothe, P., Lindholm, A., Hyvönen, A., Nenonen, S. 2012. Work environment preferences- does age make a difference? Facilities, 30(1/2), 78-95.

Rothwell, W.J., Kazanas, H.C. 2011. Mastering the instructional design process: A systematic approach. San Francisco, CA: John Wiley \& Sons.

Salas, E., Tannenbaum, S.I., Kraiger, K., Smith-Jentsch, K.A. 2012. The science of training and development in organizations: What matters in practice. Psychological Science in the Public Interest, 13(2), 74-101.

Saunders, M., Lewis, P., Thornhill, A. 2007. Research methods for business students. England: Pearson Education.

Sharit, J., Rogers, W.A., Czaja, S.J., Fisk, A.D., Charness, N. 2009. Designing for older adults: Principles and creative human factors approaches. Boca Raton, FL: CRC Press.

Stake, R.E. 1995. The art of case study research. Thousand Oaks: Sage Publications.

Sudhakar, R., Basariya, S.R. 2017. Perspectives and the factors influencing effectiveness of training and development on employees' performance. International Journal of Civil Engineering and Technology, 8(9), 135-141.

Tannenbaum, S.I. 2002. A strategic view of organizational training and learning. In Kraiger, K. (Ed.), Creating, implementing, and maintaining effective training and development: State-of-the-art lessons for practice, 10-52. San Francisco, 
CA: Jossey-Bass.

Tannenbaum, S.I., Yukl, G. 1992. Training and development in work organizations. Annual Review of Psychology, 43(1), 399-441.

Tavakol, M., Dennick, R. 2011. Making sense of Cronbach's alpha. International Journal of Medical Education, 2, 53.

Thijssen, J.G.L.1996. Leren, leeftijd ed toopbaanperspectief:Opleidingsdeelname door oudere personeelsleden als component van. Human Resource Development. [Learning, age and career prospect. Training participation of older employees as a component of HRD]. Deventer; Kluwer.

Tziner, A., Fisher, M., Senior, T., Weisberg, J. 2007. Effects of trainee characteristics on training effectiveness. International Journal of Selection and Assessment, 15(2), 167-174.

Van der Klink, J.J., Blonk, R.W., Schene, A.H., Van Dijk, F.J. 2001. The benefits of interventions for work-related stress. American Journal of Public Health, 91(2), 270.

Van Gerven, P.W., Paas, F., Tabbers, H.K. 2006. Cognitive aging and computerbased instructional design: Where do we go from here? Educational Psychology Review, 18(2), 141.

Velada, R., Caetano, A. 2007. Training transfer: The mediating role of perception of learning. Journal of European Industrial Training, 31(5), 283-296.

Wangchuk, D., Wetprasit, P. 2019. Assessment of current training program and its effectiveness in hotels of Bhutan. Journal of Quality Assurance in Hospitality \& Tourism, 20(4), 405-423.

Weiss, E.M., Kemmler, G., Deisenhammer, E.A., Fleischhacker, W.W., Delazer, M. 2003. Sex differences in cognitive functions. Personality and Individual Differences, 35(4), 863-875.

Yaqoot, E.S., Wan Mohd Noor, Wan Shakizah, Mohd Isa, M.F. 2017. Factors influencing training effectiveness: Evidence from public sector in Bahrain. Acta Universitatis Danubius, 13(2), 31-44.

Yin, R.K. 2009. Case study research: Design and methods (4th ed.). Thousand Oaks. Sage. Yoder, D. 1970. Personnel management and industrial relations. New Jersey, NJ: Prentice-Hall.

Yong, A.G., Pearce, S. 2013. A beginner's guide to factor analysis: Focusing on exploratory factor analysis. Tutorials in Quantitative Methods for Psychology, 9(2), 79-94.

\section{Appendices:}

I. Mean score of the individual factors - Gender

\begin{tabular}{llrrrrr} 
1.Gender & & Factor_1 & Factor_2 & Factor_3 & Factor_4 & Factor_5 \\
\hline \multirow{2}{*}{ Male } & Mean & 4.26 & 4.34 & 3.89 & 3.10 & 4.55 \\
\cline { 2 - 7 } Female & Std.Deviation & .56 & .50 & .73 & 1.10 & .53 \\
& Mean & 4.30 & 4.37 & 4.06 & 3.13 & 4.43 \\
\cline { 2 - 7 } Total & Std.Deviation & .58 & .55 & .68 & 1.15 & .60 \\
& Mean & 4.28 & 4.36 & 3.98 & 3.11 & 4.48 \\
& Std.Deviation & .57 & .53 & .71 & 1.13 & .57 \\
\hline
\end{tabular}

Source: Own study 
Test Statistics ${ }^{\mathrm{a}}$

\begin{tabular}{lrrrrr} 
& \multicolumn{1}{c}{ Factor_1 } & \multicolumn{1}{c}{ Factor_2 } & \multicolumn{1}{c}{ Factor_3 } & \multicolumn{1}{r}{ Factor_4 } & \multicolumn{1}{r}{ Factor_5 } \\
\hline Mann-Whitney & 17418.500 & 17079.000 & 15914.500 & 17818.500 & 16198.500 \\
\hline Wilcoxon W & 32818.500 & 32479.000 & 31314.500 & 33218.500 & 37934.500 \\
\hline Z & -.728 & -1.048 & -2.141 & -.358 & -1.977 \\
\hline Asymp.Sig.(2-tailed) & .467 & .295 & .032 & .721 & .048 \\
\hline
\end{tabular}

a. Grouping Variable: 1.Gender Source: Own study

III. Mean score of the individual factors - Age

\begin{tabular}{llrrrrr} 
2.Age & & Factor_1 & Factor_2 & Factor_3 & Factor_4 & Factor_5 \\
\hline Less & Mean & 4.09 & 3.84 & 4.13 & 3.10 & 4.00 \\
than 20 & Std.Deviation & .52 & .38 & .80 & 1.43 & .71 \\
\hline $20-29$ & Mean & 4.30 & 4.38 & 4.03 & 3.26 & 4.44 \\
\cline { 2 - 7 } $30-39$ & Std.Deviation & .61 & .55 & .71 & 1.14 & .61 \\
& Mean & 4.24 & 4.33 & 3.92 & 3.09 & 4.53 \\
\cline { 2 - 7 } $40-49$ & Std.Deviation & .50 & .48 & .68 & 1.08 & .48 \\
\hline \multirow{2}{*}{ Over } & Mean & 4.15 & 4.21 & 3.76 & 2.84 & 4.44 \\
50 & Std.Deviation & .61 & .46 & .70 & 1.11 & .60 \\
\hline \multirow{2}{*}{ Total } & Mean & 4.43 & 4.50 & 4.12 & 2.98 & 4.61 \\
& Std.Deviation & .49 & .53 & .74 & 1.15 & .53 \\
\hline & Mean & 4.28 & 4.36 & 3.98 & 3.11 & 4.48 \\
\hline
\end{tabular}

Source: Own study.

IV. Kruskal Wallis Test-Age

Test Statistics

\begin{tabular}{lrrrrr} 
& Factor_1 & \multicolumn{1}{c}{ Factor_2 } & Factor_3 & Factor_4 & \multicolumn{1}{c}{ Factor_5 } \\
\hline Chi-Square & 10.073 & 18.474 & 10.795 & 6.658 & 7.065 \\
df & 4 & 4 & 4 & 4 & 4 \\
\hline Asymp.Sig. & .039 & .001 & .029 & .155 & .133 \\
\hline
\end{tabular}

a. Kruskal Wallis Test

b. Grouping Variable: 2.Age

Source: Own study.

$\boldsymbol{V}$. Mean score of the individual factors - Industry Sector

\begin{tabular}{llrrrrr} 
4.Industry sector you work in & Factor_1 & Factor_2 & Factor_3 & Factor_4 & Factor_5 \\
\hline Banking & Mean & 4.23 & 4.23 & 3.89 & 2.82 & 4.42 \\
\cline { 2 - 7 } Accounting & Std.Deviation & .44 & .58 & .55 & 1.22 & .58 \\
\cline { 2 - 7 } & Mean & 4.42 & 4.29 & 4.12 & 3.15 & 4.33 \\
\cline { 2 - 7 } Insurance & Std.Deviation & .575 & .57 & .76 & 1.32 & .66 \\
\cline { 2 - 7 } & Mean & 4.21 & 4.36 & 3.93 & 3.08 & 4.47 \\
\hline Investments & Mean & .55 & .54 & .68 & 1.02 & .59 \\
\& Advisory & Std.Deviation & 4.30 & 4.43 & 3.96 & 3.34 & 4.61 \\
\hline Other & Mean & .57 & .41 & .75 & 1.06 & .43 \\
\hline
\end{tabular}




\begin{tabular}{llrrrrr}
\hline \multirow{3}{*}{ Total } & Std.Deviation & .69 & .49 & .78 & 1.19 & .46 \\
& Mean & 4.28 & 4.36 & 3.98 & 3.11 & 4.48 \\
\cline { 2 - 6 } & Std.Deviation & .57 & .53 & .71 & 1.13 & .57 \\
\hline
\end{tabular}

Source: Own study.

VI. Kruskal Wallis Test - Industry Sector

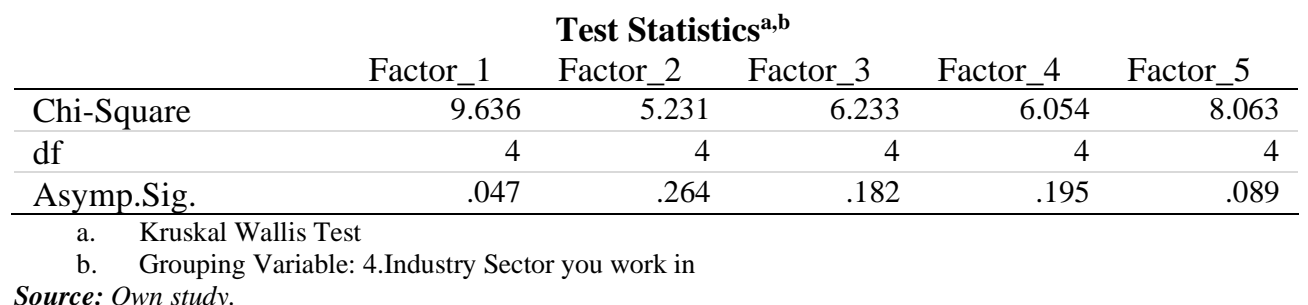

Table VII. Mean score of the individual factors - Current Occupation

\begin{tabular}{llrrrrr} 
7.Current Occupation & Factor_1 & Factor_2 & Factor_3 & Factor_4 & Factor_5 \\
\hline \multirow{2}{*}{ Manual } & Mean & 3.40 & 3.76 & 3.40 & 3.60 & 3.80 \\
\cline { 2 - 7 } Clerical & Std.Deviation & 1.47 & 1.76 & 1.48 & 1.67 & 1.79 \\
& Mean & 4.25 & 4.29 & 3.99 & 3.06 & 4.41 \\
\cline { 2 - 7 } Managerial & Std.Deviation & .51 & .45 & .62 & 1.18 & .50 \\
& Mean & 4.25 & 4.35 & 3.89 & 3.00 & 4.48 \\
\cline { 2 - 7 } Professional & Std.Deviation & .48 & .54 & .69 & 1.05 & .58 \\
\cline { 2 - 7 } & Mean & 4.30 & 4.40 & 4.02 & 3.11 & 4.55 \\
\cline { 2 - 7 } Other & Std.Deviation & .61 & .51 & .75 & 1.10 & .55 \\
& Mean & 4.56 & 4.57 & 4.21 & 3.72 & 4.63 \\
\hline \multirow{2}{*}{ Total } & Std.Deviation & .48 & .33 & .66 & 1.09 & .51 \\
& Mean & 4.28 & 4.36 & 3.98 & 3.11 & 4.48 \\
\hline & Std.Deviation & .57 & .53 & .71 & 1.13 & .57 \\
\hline
\end{tabular}

Source: Own study.

VIII. Kruskal Wallis Test-Current Occupation

\begin{tabular}{lrrrrrr} 
& \multicolumn{2}{c}{ Test Statistics } & & & \\
& Factor_1 & \multicolumn{1}{c}{ Factor_2 } & Factor_3 & Factor_4 & \multicolumn{1}{l}{ Factor_5 } \\
\hline Chi-Square & 12.178 & 8.810 & 7.511 & 10.163 & 8.131 \\
\hline df & 4 & 4 & 4 & 4 & 4 \\
\hline Asymp.Sig. & .016 & .066 & .111 & .038 & .087 \\
\hline
\end{tabular}

a. Kruskal Wallis Test

b. Grouping Variable: 7. Current Occupation

Source: Own study. 